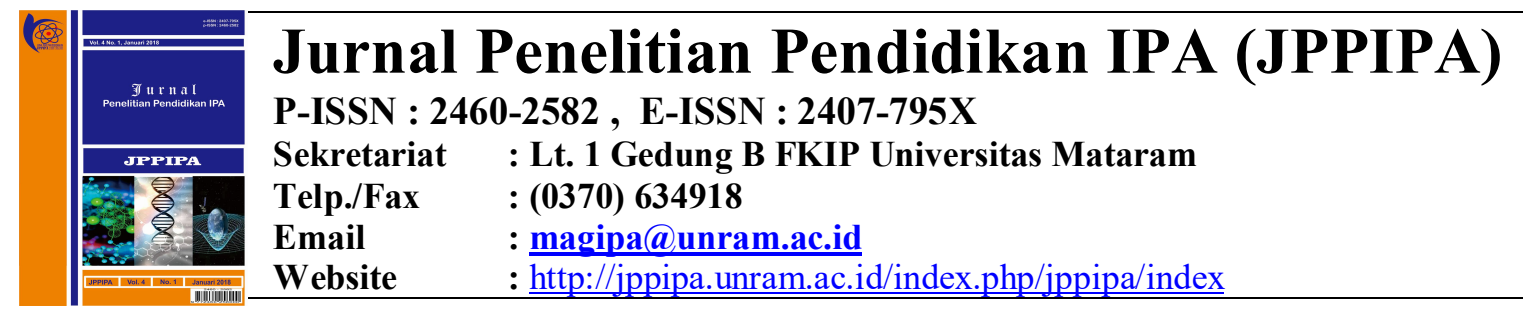

\title{
UJI AKTIVITAS ANTIOKSIDAN DAN PENAPISAN FITOKIMIA DARI EKSTRAK DAUN PAKOASI DAN KLUWIH SEBAGAI SUMBER ANTIOKSIDAN ALAMI
}

\author{
Nurlaila Agustikawati ${ }^{1}$, Yayuk Andayani ${ }^{2}$, Dedy Suhendra ${ }^{3}$ \\ Program Studi Magister Pendidikan IPA, Program Pascasarjana Universitas Mataram ${ }^{1,2,3}$ \\ Email: ella.agustika.ea@gmail.com
}

\begin{tabular}{|c|c|}
\hline Key Words & Abstract \\
\hline $\begin{array}{l}\text { Antioxidant } \\
\text { activity, } \\
\text { phytochemical } \\
\text { analysis } \\
\text { ethanol } \\
\text { extract, green } \\
\text { bean leaves, } \\
\text { kluwih leaves, } \\
\text { leaves of } \\
\text { pakoasi }\end{array}$ & $\begin{array}{l}\text { This study aims to determine the antioxidant activity and secondary metabolism } \\
\text { of pakoasi leaf extract and kluwih leaf. Analysis using DDPH method (1,1- } \\
\text { diphenyl-2-picrylhydrazyl). Result of antioxidant activity test in. Concentration } \\
\text { Barriers (IC50). IC50 values for leaf extract of pakoasi and kluwih leaves were } \\
89.659 \mu \mathrm{g} \text { / mL and } 54.719 \mu \mathrm{g} \text { / mL greater than IC50 vitamin C of } 46.74 \mu \mathrm{g} / \\
\text { mL. Qualitative analysis of antioxidant compounds using TLC technique showed } \\
\text { seven chromatogram profiles for pakoasi leaf extract and four chromatogram } \\
\text { profiles for kluwih leaf extract. In addition, phytochemical analysis of leaf } \\
\text { extract of pakoasi and kluwih leaves showed the presence of saponin } \\
\text { compounds, tannins, phenols, flavonoids, steroids and triterpenoids. Based on } \\
\text { the results of this analysis concluded that leaf extract of pakoasi and kluwih leaf } \\
\text { as natural source of antioxidant which can be seen with IC50 value in the } \\
\text { sample is in strong category and supported from phytolyte analysis result which } \\
\text { according to phenol and flavonoid which act as antioxidant. }\end{array}$ \\
\hline Kata Kunci & Abstrak \\
\hline $\begin{array}{l}\text { Aktivitas } \\
\text { antioksidan, } \\
\text { Analisis } \\
\text { fitokimia } \\
\text { Ekstrak etanol, } \\
\text { Daun buncis, } \\
\text { Daun kluwih, } \\
\text { Daun pakoasi }\end{array}$ & $\begin{array}{l}\text { Penelitian ini bertujuan untuk mengetahui aktivitas antioksidan dan } \\
\text { mengidentifikasi senyawa metabolit sekunder dari ekstrak daun pakoasi } \\
\text { dan daun kluwih. Analisis dilakukan menggunakan metode DDPH }(1,1- \\
\text { diphenyl-2-pikrylhydrazyl). Hasil uji aktivitas antioksidan dinyatakan } \\
\text { dalam nilai Inhibition Concentration }\left(\mathrm{IC}_{50} \text { ). Nilai } \mathrm{IC}_{50} \text { untuk ekstrak daun }\right. \\
\text { pakoasi dan daun kluwih berturut-turut } 89,659 \mu \mathrm{g} / \mathrm{mL} \text { dan } 54,719 \mu \mathrm{g} / \mathrm{mL} \\
\text { lebih besar dibandingkan dengan nilai } \mathrm{IC}_{50} \text { vitamin } \mathrm{C} \text { yaitu } 46,74 \mu \mathrm{g} / \mathrm{mL} \text {. } \\
\text { Analisis kualitatif senyawa antioksidan menggunakan teknik KLT } \\
\text { menunjukkan adanya tujuh profil kromatogram untuk ekstrak daun } \\
\text { pakoasi dan empat profil kromatogram untuk ekstrak daun kluwih. Selain } \\
\text { itu analisis fitokimia ekstrak daun pakoasi dan daun kluwih menunjukkan } \\
\text { adanya kandungan senyawa saponin, tanin, fenol, flavonoid, steroid dan } \\
\text { triterpenoid. Berdasarkan hasil analisis ini disimpulkan bahwa ekstrak } \\
\text { daun pakoasi dan daun kluwih berpotensi sebagai sumber antioksidan } \\
\text { alami yang dapat dilihat dengan nilai IC } 50 \text { pada sampel berada dalam } \\
\text { kategori kuat dan didukung dari hasil analisis fitokimia yang } \\
\text { mengidentifikasi adanya senyawa fenol dan flavonoid yang berperan } \\
\text { sebagai antioksidan. }\end{array}$ \\
\hline
\end{tabular}

\section{PENDAHULUAN}

Berbagai penyakit, seperti kanker kulit, diabetes melitus, kegagalan ginjal, penyakit kardiovaskuler, katarak dan penuaan dini telah diketahui erat kaitannya dengan radikal bebas (Astawan, 2004). 
Senyawa radikal bebas dalam tubuh terbentuk dari proses metabolisme normal tubuh atau dapat terbentuk dari luar tubuh. Sumber dalam tubuh misalnya terbentuk dari xanthine oxidase, mitokondria, fagositosis, reaksi oleh besi atau logam transisi lain, pembentukan arakidonat, peroksisom, inflamasi, serta olahraga. Sumber dari luar tubuh terbentuk dari asap rokok, polusi lingkungan, radiasi, obatobatan, pestisida, anestetik, limbah industri, ozon, serta sinar ultraviolet (Agarwal, et al., 2010).

Radikal bebas adalah spesi kimia yang tidak memiliki pasangan elektron dikulit terluar sehingga sangat reaktif dan mampu bereaksi dengan protein, lipid, karbohidrat atau DNA. Reaksi antara radikal bebas dengan molekul-molekul ini akan berakibat pada timbulnya suatu penyakit (Rao dkk, 2011). Reaksi radikal bebas dapat menimbulkan berbagai panyakit seperti kanker, jantung, katarak, penuaan dini, serta penyakit degenerative lainnya (Barus, 2009).

Radikal bebas yang merusak tubuh dapat dinetralisir oleh senyawa antioksidan. Antioksidan merupakan senyawa yang dapat menghambat oksigen reaktif dan radikal bebas dalam tubuh. Senyawa antioksidan ini akan menyerahkan satu atau lebih elektron kepada radikal bebas sehingga menjadi bentuk molekul yang normal kembali dan menghentikan berbagai kerusakan yang ditimbulkan. Kerusakan oksidatif atau kerusakan akibat radikal bebas dalam tubuh pada dasarnya dapat diatasi oleh antioksidan endogen seperti enzim catalase, glutathione peroxidase, superoxide dismutase, dan glutathione Stransferase. Namun jika senyawa radikal bebas terdapat berlebih dalam tubuh atau melebihi batas kemampuan proteksi antioksidan seluler, maka dibutuhkan antioksidan tambahan dari luar atau antioksidan eksogen untuk menetralkan radikal yang terbentuk (Reynertson, 2007).

Berdasarkan sumbernya, antioksidan dapat digolongkan menjadi dua jenis yaitu antioksidan alami dan antioksidan sintesis. Menurut Tristantodkk (2014) penggunaan antioksidan sintesis yang umum digunakan adalah butylated hydroxyl toluene (BHT), butylated hydroxyl anysol (BHA), butylated hydroxyl quione (BHQ) dan Propylgallate (PG). Penggunaan antioksidan sintesis dalam bidang industry pangan tidak direkomendasikan oleh badan pengawas obat dan makanan (Barus, 2009). Selain itu, dibutuhkan antioksidan alami sebagai alternatif dalam bidang kesehatan dan industri (Subiyandono, 2013).

Studi epidemiologi menunjukkan bahwa beberapa tanaman dan buah-buahan terbukti bermanfaat melindungi tubuh manusia terhadap bahaya radikal bebas (Rohman dan Riyanto, 2010). Hal ini dikarenakan potensi antioksidan yang terdapat dalam tanaman dan buah-buahan tersebut, seperti karoten, flavonoid, komponen fenolik lain, vitamin $\mathrm{C}$ dan $\mathrm{E}$ (Windono et al, 2001). Antioksidan alami banyak ditemukan pada tanaman seperti biji-bijian, buah dan sayur-sayuran yang mempunyai manfaat bagi kesehatan.

Beberapa tanaman telah dilakukan pengujian terhadap beberapa penyakit antara lain ekstrak pakoasi sebagai antikolestrol (Ikewuchi, 2011) dan ekstrak daun kluwih sebagai antidiabetes (Marianne dkk., 2011). Hal ini diperkuat dengan adanya penelitian oleh Marianne dkk., (2014) bahwa ekstrak etanol pakoasi mengandung senyawa alkaloid, flavonoid, tannin dan asam amino. Dalam penelitian yang dilakukan oleh Mariana dkk., (2013) bahwa daun kluwih mengandung senyawa flavonoid.

Pemanfaatan tanaman kluwih selama ini hanya pada buah dan batangnya, sedangkan tanaman pakoasi dianggap hama. Sementara ketersediaan kimia aktif dari daun sangatlah melimpah diantaranya alkaloid, pectin, resin, vitamin-vitamin, mineral, senyawa aromatis, klorofil, flavanol, katekin, protein danasam amino pada daun teh (Towaha dan Balittri, 2013). 
Pemanfaatan tanaman obat didasari dari kandungan kimia aktif pada tanaman tersebut yang sebagian besar merupakan senyawa metabolit sekunder. Senyawa metabolit sekunder inilah yang berperan sebagai antioksidan alami. Selama ini penelitian tentang antioksidan alami dilakukan pada buah dan batang tanaman, sehingga dalam penelitian ini akan dilakukan uji aktivitas antioksidan dengan metode DPPH dan identifikasi senyawa metabolit sekunder dari ekstrak daun pakoasi dan daun kluwih melalui penapisan fitokimia yang berpotensi sebagai sumber antioksidan alami.

\section{METODOLOGI}

\section{Alat dan Bahan}

Alat yang digunakan pada penelitian ini adalah alat-alat gelas yang umum di laboratorium, blender, neraca analitik, pipet volumetri, rotary evaporator, alat KLT dan spektrofotometer UV Light \& UV Kon XL/XS, lampu UV $\lambda_{254}$ dan $\lambda_{365}$.

Sedangkan bahan yang digunakan dalam penelitian ini adalah daun kluwih dan daun pakoasi, aquades, etanol $70 \%$ teknis dan p.a, plat KLT GF 254 , n-heksan, etil asetat, serbuk magnesium, asam klorida pekat $37 \% \mathrm{v} / \mathrm{v}, \mathrm{H}_{2} \mathrm{SO}_{4}$ pekat $97 \%$ $\mathrm{v} / \mathrm{v}, \mathrm{NH}_{4} \mathrm{OH}, \mathrm{FeCl}_{3} 1 \% \mathrm{v} / \mathrm{v}, \mathrm{FeCl}_{3} 5 \% \mathrm{w} / \mathrm{v}$, larutan amoniak, klorofom, pereaksi Dragendorff, pereaksi Meyer, anhidrat asetat, amil-alkohol, DPPH Merck, vitamin $\mathrm{C}$.

\section{Ekstraksi}

Daun pakoasi dan kluwih dikeringanginkan selama 5 hari kemudian diblender dan diayak untuk mendapatkan sampel dalam bentuk serbuk yang lebih halus. Hal ini bertujuan untuk memperluas daerah penyerapan oleh pelarut pada saat proses ekstraksi. Sampel yang telah halus dimaserasi menggunakan pelarut etanol $70 \%$. Ekstrak sampel diperoleh dengan merendam 100 gr serbuk sampel dengan 1L etanol $70 \%$ selama $2 \times 24$ jam Filtrat yang dihasilkan dilanjutkan dengan proses evaporasi dan pemanasan sehingga diperoleh ekstrak kental daun pakoasi dan kluwih sebanyak 13,75gr dan 11,92 gr.

\section{Analisis Fitokimia}

\section{Uji Alkaloid}

0,1 gr ekstrak sampel dilarutkan dalam

$10 \mathrm{~mL} \mathrm{CHCL}_{3}$ dan 4 tetes $\mathrm{NaOH}$ kemudian saring kedalam tabung reaksi dan kocok. Tambahkan $\mathrm{H}_{2} \mathrm{SO}_{4}$ dan kocok sampai terbentuk 2 lapisan. Lapisan yang berada diatas diambil untuk diujikan masing-masing dengan pereaksi Meyer dan Pereaksi Dragendorf. Ekstrak sampel yang positif mengandung alkaloid dengan pereaksi Meyer akan menghasilkan endapan putih dan pereaksi Dragendorf menghasilkan endapan jingga.

\section{Pengujian Saponin}

0,1 gr ekstrak sampel ditambahkan 10 $\mathrm{mL}$ aquades yang dipanaskam selama 5 menit kemudian saring kedalam tabung reaksi. Tambahkan 4 tetes $\mathrm{HCl} 2 \mathrm{M}$ kemudian kocok kuat. Hasil uji positif saponin ditandai dengan terbentuknya busa yang stabil selama 10 menit.

\section{Uji Tanin}

0,1 gr ekstrak sampel ditambahkan aquades yang dipanaskan selama 5 menit lalu saring kedalam tabung reaksi, kemudian tambahkan 3 tetes $\mathrm{FeCl}_{3} 1 \%$. Hasil uji positif ditunjukkan terbentuknya warna hijau kehitaman pada larutan sampel.

\section{Uji Fenol}

0,1 gr ekstrak sampel ditambahkan aquades yang dipanaskan selama 5 menit lalu saring, kemudian tambahkan 3 tetes $\mathrm{FeCl}_{3}$ 5\%. Hasil uji positif ditunjukkan dengan terbentuknya warna hijau pada larutan sampel.

\section{Uji Flavonoid}

0,1 gr ekstrak sampel ditambahkan 10 $\mathrm{mL}$ aquades dan dipanaskan selama 5 menit lalu saring. Tambahkan $0,5 \mathrm{mg}$ serbuk $\mathrm{Mg}, 1 \mathrm{~mL} \mathrm{HCl}$ dan $1 \mathrm{~mL}$ amilalkohol kemudian kocok dengan kuat. Hasil positif ditandai dengan 
terbentuknya warna merah, kuning atau jingga pada larutan sampel.

\section{Uji Steroid dan Triterpenoid}

0,1 gr ekstrak sampel dilarutkan dalam $2 \mathrm{~mL}$ kloroform lalu tambahkan 10 tetes anhidrida asetat dan 3 tetes $\mathrm{H}_{2} \mathrm{SO}_{4}$ pekat melalui dinding tabung reaksi. Hasil positif triterpenoid ditandai terbentuknya cincin kecoklatan dan munculnya warna hijau menandakan adanya steroid.

\section{Analisis Senyawa Antioksidan Metode KLT}

0,5 gr ekstrak sampel dilarutkan dengan etanol 70\%. Campurkan eluen nheksan: kloroform dengan perbandingan $2: 8$. Setelah elusi selesai keringkan plat kemudian semprotkan dengan larutan DPPH 0,5 mM. Uji positif antioksidan ditandai dengan bercak kuning dengan latar belakang ungu.

\section{Analisis Aktivitas Antioksidan dengan Metode DPPH}

Larutkan ekstrak sampel kemudian buatkan variasi larutan 500, 400, 300, 200 dan $100 \mathrm{ppm}$ masing-masing $10 \mathrm{~mL}$. masing-masing larutan ditambahkan $1 \mathrm{~mL}$ larutan DPPH $0,5 \quad \mathrm{mM}$ kemudian diinkubasi selama 30 menit dalam ruang gelap. Ukur pada panjang gelombang maksimum (517 nm (Kurnia, 2013)). Nilai persentasi daya hambat yang diwakili oleh nilai $\mathrm{IC}_{50}$ dihitung dengan rumus:

$$
\% \text { inhibisi }=\frac{(\text { b blankol }- \text { A ekstrak })}{\text { A blangko }} \times 100 \%
$$

Keterangan:

$$
\begin{gathered}
\text { A blangko = } \\
\text { serapan radikal DPPH } \\
0,5 \mathrm{mM} \\
\text { A sampel }=\text { serapan radikal DPPH } \\
\text { Setelah ada sampel }
\end{gathered}
$$

Hasil dibuatkan kurva untuk memperoleh persamaan regresi dengan konsentrasi ekstrak $(\mu \mathrm{g} / \mathrm{mL})$ sebagai absis (sumbu $x$ ) dan nilai \% inhibisi sebagai ordinat (sumbu y). Nilai $\mathrm{IC}_{50}$ dihitung pada saat nilai \% inhibisi sebesar 50\% dengan menggunakan persamaan $\mathrm{Y}=\mathrm{ax}+\mathrm{b}$ (Wijaya dkk, 2014).

\section{HASIL DAN PEMBAHASAN Senyawa Antioksidan dalam Ekstrak Daun Pakoasi dan Kluwih}

Berdasarkan hasil analisis kulaitatif senayawa antioksidan dengan teknik KLT diperoleh beberapa profil kromatogram senyawa antioksidan dengan nilai $\mathrm{Rf}$ pada ekstrak daun pakoasi $(0,14,0,20,0,28$, $0,36,0,46,0,520,56)$ dan ekstrak daun kluwih $\quad(0,12, \quad 0,18, \quad 0,28, \quad 0,36)$. Berdasarkan nilai $\mathrm{Rf}$ tersebut ekstrak daun pakoasi dan daun kluwih memiliki senyawa antioksidan yang sama yang dapat dilihat dari nilai $\mathrm{Rf}$ yang sama pada 0,36 .

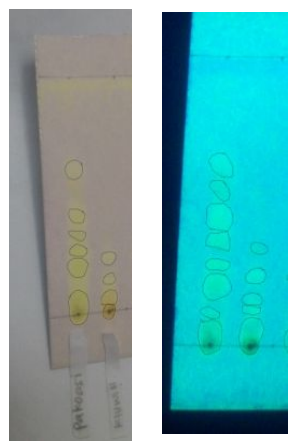

Gambar 1 Hasil Uji KLT senyawa antioksidan (a) setelah penyemprotan DPPH (c) dibawah lampu UV $366 \mathrm{~nm}$

\section{Aktivitas Antioksidan Ekstrak Daun Pakoasi dan Kluwih}

Hasil uji aktivitas antioksidan dengan DPPH disajikan dalam bentuk kurva hubungan persen penghambatan dengan konsentrasi sampel sehingga diperoleh persamaan regresi untuk menentukan nilai $\mathrm{IC}_{50}$. Semakin tinggi konsentrasi sampel yang digunakan untuk bereaksi dengan DPPH semakin turun nilai absorbansinya yang berarti semakin tinggi persen penghambatan terhadap radikal DPPH oleh antioksidan.

Aktivitas antioksidan digambarkan pada nilai $\mathrm{IC}_{50}$ pada vitamin $\mathrm{C}$, ekstrak daun pakoasi dan daun kluwih secara berurutan yaitu $46,74 \mu \mathrm{g} / \mathrm{mL}, 89,65 \mu \mathrm{g} / \mathrm{mL}$ 
dan 54,72 $\mu \mathrm{g} / \mathrm{mL}$. Hasil uji aktivitas

Tabel 1.

antioksidan dapat dilihat dalam grafik pada

Tabel 1. Data Hasil Uji Aktivitas Antioksidan Vitamin C, Ekstrak Daun Pakoasidan Kluwih

\begin{tabular}{cccccc}
\hline Sampel & $\begin{array}{c}\text { Konsentrasi } \\
(\mathrm{ppm})\end{array}$ & $\begin{array}{c}\text { Absorbansi } \\
(\mathrm{A})\end{array}$ & $\begin{array}{c}\text { Daya } \\
\text { Hambat } \\
(\%)\end{array}$ & $\begin{array}{c}\text { Pers. Regresi } \\
(\mathrm{y}=\mathrm{ax}+\mathrm{b})\end{array}$ & $\begin{array}{c}\mathrm{IC}_{50} \\
(\mu \mathrm{g} / \mathrm{mL})\end{array}$ \\
\hline \multirow{3}{*}{ Vitamin C } & 100 & 0,145 & 55,65 & & \\
& 200 & 0,119 & 63,60 & & \\
& 300 & 0,099 & 69,72 & $\mathrm{y}=0,089 \mathrm{x}+45,84$ & 46,74 \\
& 400 & 0,054 & 83,48 & & \\
Ekstrak Daun & 500 & 0,032 & 90,214 & & \\
Pakoasi & 100 & 0,168 & 48,62 & & \\
& 300 & 0,125 & 61,77 & & \\
& 400 & 0,097 & 70,33 & $\mathrm{y}=0,088 \mathrm{x}+42,11$ & \\
& 500 & 0,074 & 77,37 & & \\
Ekstrak Daun & 0,049 & 85,01 & & \\
Kluwih & 100 & 0,156 & 52,29 & & \\
& 300 & 0,118 & 63,91 & & \\
& 400 & 0,085 & 74,006 & $\mathrm{y}=0,089 \mathrm{x}+45,13$ & \\
\hline
\end{tabular}

Aktivitas antioksidan dapat dilihat dari penurunan intensitas warna DPPH yang memudar dari ungu menjadi kuning (Molenuux, 2004). Hal ini dikarenakan semakin banyak atom hidrogen yang didonorkan oleh ekstrak sampel untuk menghambat radikal DPPH mengakibatkan meningkatnya kompleks non radikal DPPH sehingga karakteristik radikal DPPH menurun. Semakin besar konsentrasi ekstrak sampel, warna kuning pada larutan uji yang dihasilkan akan semakin kuat (Widyaningsih, 2010).. Secara umum reaksi radikal DPPH dengan antioksidan dapat dilihat pada Gambar 1.

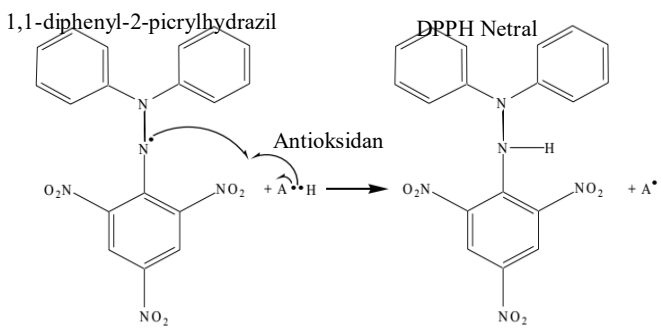

Gambar 1 Reaksi Umum Radikal DPPH dengan Antioksidan (Windono et al., 2001)
Antioksidan $\quad(\mathrm{A} \cdot \bullet \mathrm{H}) \quad$ yang mempunyai fungsi utama yang sering disebut sebagai antioksidan primer. Senyawa ini dapat memberikan atom hidrogen secara cepat ke radikal DPPH atau mengubahnya ke bentuk lebih stabil, sementara turunan radikal antioksidan $(\mathrm{A} \bullet)$ tersebut memiliki keadaan lebih stabil dibanding radikal DPPH. Radikal-radikal antioksidan $(\mathrm{A} \bullet)$ yang terbentuk pada reaksi tersebut relatif stabil dan tidak mempunyai cukup energi untuk dapat bereaksi dengan molekul lain membentuk radikal bebas baru.

\section{Metabolit Sekunder dalam Ekstrak Daun Pakoasi dan Kluwih}

Analisis kualitatif senayawa antioksidan dengan teknik KLT diperkuat dengan hasil uji fitokimia yang menunjukkan ekstrak daun pakoasi dan kluwih positif mengandung flavonoid, fenol tannin, saponin, steroid dan triterpenoid. Hasil uji fitokimia secara keseluruhan ditunjukkan pada Tabel 2. 
Tabel 2. Hasil Uji Fitokimia Ekstrak daun Pakoasi, ekstrak daun Kluwih dan ekstrak daun Buncis

\begin{tabular}{|c|c|c|c|c|}
\hline $\begin{array}{l}\text { Hasil analisis } \\
\text { Fitokimia }\end{array}$ & Pereaksi & Hasil Pengamatan & $\begin{array}{c}\text { Ekstrak } \\
\text { daun } \\
\text { pakoasi }\end{array}$ & $\begin{array}{c}\text { Ekstrak } \\
\text { daun } \\
\text { kuwih }\end{array}$ \\
\hline \multirow[t]{2}{*}{ Alkaloid } & Meyer & Tidak terbentuk endapan putih & - & - \\
\hline & Dragendorf & $\begin{array}{c}\text { Tidak terbentuk endapan } \\
\text { merah bata }\end{array}$ & - & - \\
\hline Flavonoid & $\begin{array}{l}\mathrm{Mg}, \mathrm{HCl} \text { pekat } \\
\text { amilalkohol }\end{array}$ & $\begin{array}{c}\text { Terbentuk warna kuning atau } \\
\text { jingga }\end{array}$ & + & + \\
\hline Tannin & $\mathrm{FeCl}_{3} 1 \%$ & $\begin{array}{c}\text { Terbentuk warna hijau } \\
\text { kehitaman }\end{array}$ & + & + \\
\hline Saponin & Air panas dan $\mathrm{HCl}$ & Timbul busa & + & + \\
\hline Fenol & $\mathrm{FeCl}_{3} 5 \%$ & Terbentuk warna hijau & - & + \\
\hline $\begin{array}{l}\text { Triterpenoid } \\
\text { dan steroid }\end{array}$ & Liebermann-Burchard & $\begin{array}{l}\text { Terbentuk cincin kecoklatan } \\
\text { dan larutan berwarna hijau }\end{array}$ & + & + \\
\hline
\end{tabular}
Keterangan:
$(-)=$ tidak terdapat kandungan
$(+)=$ Terdapat kandungan

Berdasarkan uji fitokimia menunjukkan keberadaan senyawa flavonoid, fenol, tannin, saponin, steroid dan triterpenoid menunjukkan bahwa ekstrak daun pakoasi dan daun kluwih berpotensi sebagai sumber antioksidan alami.

Efektifitas senyawa flavonoid dalam menangkal radikal DPPH sebagian besar bergantung pada struktur, hidrofobisitas, aktivitas biologis dan aktivitas oksidatif. Kemampuan pemutusan reaksi berantai radikal oleh flavonoid terutama bergantung pada kehadiran setidaknya dua kelompok $o$-hidroksil pada cincin B. hal ini memungkinkan pembentukan ikatan hidrogen intramolekul antara kelompok hidroksil yang meningkatkan stabilitas radikal fenoksil. Struktur kimia senyawa flavonoid sebagai antiokidan dapat dilihat pada Gambar 5.12.

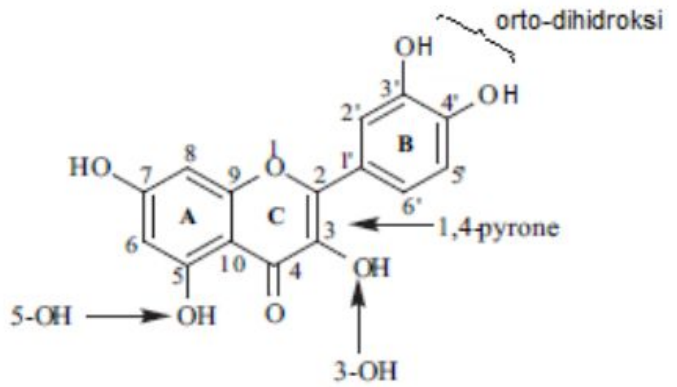

Gambar 5.12 struktur kimia senyawa flavonoid sebagai antioksidan
Dijelaskan lebih lanjut bahwa grup hidroksil pada cincin B senyawa flavonoid mendonorkan ion hidrogen dengan mendonorkan sebuah electron ke radikal hidroksil dan peroksil sehingga menstabilkan kedua radikal tesebut dan membentuk radikal flavonoid yang relative stabil (Heim et al., 2002).

Selain senyawa polifenol, senyawa triterpenoid juga diketahui memiliki aktivitas antioksidan yang tinggi. Sedangkan saponin yang mampu meredam superoksida melalui pembentukan intermediet hidroperoksida sehingga mencegah kerusakan biomolekular oleh radikal bebas (Yuhernita dan Juniarti, 2011).

Golongan senyawa yang aktif sebagai antioksidan pada batang, buah dan daun mengkudu berasal dari senyawa flavonoid (Crichtonet. al, 2013) dan triterpenoid, tannin, dan steroid glikosida dapat berperan sebagai antioksidan dan antimikroba (iwalukom et. al, 2007).

Hal ini diperkuat dengan nilai $\mathrm{IC}_{50}$ pada ketiga ekstrak sampel menunjukkan bahwa aktivitas antioksidannya berada dalam kategori kuat karena nilai $\mathrm{IC}_{50}$ ketiga ekstrak sampel berada diantara 50 ppm sampai 100 ppm (Putranti, 2013). 
KESIMPULAN

Berdasarkan dari hasil penelitian yang telah dilakukan dapat diambil kesimpulan sebagai berikut:

1. Senyawa metabolit sekunder yang terkandung dalam ektrak daun pakoasi, daun kluwih dan daun buncis adalah flavonoid, tannin, saponin, fenol, steroid dan triterpenoid.

2. Aktivitas antioksidan pada ekstrak daun pakoasi, daun kluwih dan daun buncis dikategorikan antioksidan kuat sehingga berpotensi dijadikan sebagai sumber antioksidan alami

\section{DAFTAR PUSTAKA}

Agarwal, A., Thompson, A., Kothari, S., Plessis, S. 2010. Free Radicals: Their Beneficial and Detrimental Effects on Sperm Function. Indian Journal of Experimental Biology, 48 (9): 425-435

Barus, Pina. 2009. Pemanfaatan Bahan Pengawet dan Antioksidan Alami pada Industri Bahan Makanan. Pidato Pengukuhan Jabatan Guru Besar Tetap dalam Bidang Kimia Analitik. Rapat terbuka Universitas Sumatera Utara: Medan

Crichton, G.E., Bryan, J., Murphy, K.J. 2013. Dietary antioxidants, cognitive function and dementia--a systematic review. Plant Foods for Human Nutrition68 (3): 279-92

Iwalokum, B.A., Usen, U.A., Otunba, A.A., Olukoya, D.K. 2007. Comparative phytochemical evaluation, antimicrobial and antioxidant properties of Pleurotus ostreatus. African Biotechno. 6:1732-1739.

Kurnia, Nova. 2013. Uji Aktivitas Antioksidan Ekstrak Air Buah
Buncis (Phaseolus vulgaria L.). Tesis S2 Universitas Mataram

Mariana, L., Andayani, Y., Gunawan, E.R. 2013. Analisis Senyawa Flavonoid Hasil Fraksinasi Ekstrak Diklorometana Daun Kluwih. Chemistry Progress 6 (2)

Marianne., Yuandani., Rosnani. 2011. Antidiabetic Activity from Ethanol Extract of Kluwih's Leaf (Artocarpus camansi). Jurnal Natural 11 (2)

Marianne., Lestari, D., Sukandar, EY., Kurniati, NF.,Nasution, R. 2014. Antidiabatic Activity of Leaves Ethanol Chromolaaena odorata (L.) R.M. king on Induced Male Mice with Alloxan Monohydrate. Jurnal Natural 14 (1): 1-4 ISSN 1141-8513

Molyneux, P. 2004. The Use of the Stable Free Radical Diphenylpicrylhidrazyl (DPPH) for Estimating Antioxidant Activity. Songklanakaring Journal Science of Technology. 26 (2): 211219

Putranti, Ristiyana Ika. 2013. Skrining Fitokimia dan Aktivitas Antioksidan Ekstrak Rumput Laut Sargassum duplicatum dan Turbinaria ornate Dari Jepara. Tesis S2.Universitas Diponegoro Semarang

Rao, S.P., Kava, S., Yerramili, A., Mamidi, A. 2011. Free Radicals and Tissue Demage: Role of Antioxidants. Free Radicals and Antioxidants Journal, 1 (4)

Reynertson, K. A., 2007, Phytochemical Analysis of Bioactive Constituens from Edible Myrtaceae Fruit, Dissertation, The City University of New York, New York. 
Rohman, A., Riyanto, S., Yuniarti, N., Saputra, W. R., Utami, R. \& Mulatsih, W., 2010, Antioxidant activity, total phenolic, and total flavaonoid of extracts and fractions of red fruit (Pandanus conoideus Lam), International Food Research Journal,17, 97-106

Subiyandono. 2013. Uji Aktivitas Antioksidan Ekstrak Camellia sinensis, Hibicus sabdariffa dan Phaleria macrocarpa (Scheff.) Boerl. Secara Spektofotometri dengan DPPH. Jurusan Farmasi POLTEKES DEPKES Palembang

Tristanto, R., Putri, M.A., Situmorang, A.P., Suryanti. 2014. Optimalisasi Pemanfaatan Daun Lamun Thalassia hemprichii sebagai sumber antioksidan alami. Available online at Indonesian Journal of Fisheries Science and Techonology (IJFST) Vol. 10 No.1: 26-29

Towaha, J. dan Balittri. 2013. Kandungan Senyawa Kimia pada Daun The (Camellia sinensis). Warta Penelitian dan Pengembangan Tanaman Industri, Volume 19 Nomor 3

Widyaningsih, W. 2010. Uji Aktivitas Antioksidan Ektrak Etanol Daun Dewa (Gynura procumbens) dengan Metode DPPH (1,1-difenil2-pikrilhidrazil). [Proiding Seminar Nasional Kosmetika Alami]

Wijaya, Dwi Putra., Paendong, Jessy E., Abijulu, Jemmy. 2014. Skrining Fitokimia dan Uji Aktivitas Antioksidan dari Daun Nasi (Phrynium capitatum) dengan Metode DPPH (1,1-difenil-2pikrilhidrazil).Jurnal Mipa Unsrat Online 3 (1) 11-15
Windono, T., Soediman, S., Yudawati, U., Ermawati, E., Srielita, A. \& Erowati, T. i., 2001, Uji Peredaman Radikal Bebas Terhadap 1,1Diphenyl-2-Picrilhydrazil (DPPH) dari Ekstrak Kulit Buah dan Biji Anggur (Vitis viniferaL.) Probolinggo Biru dan Bali, Artocarpus, Vol.1 No.1, 34-43 